\title{
KONSEP PEMIKIRAN TAQIYUDIN AN NABHANI TENTANG KEPRIBADIAN ISLAM DAN IMPLIKASINYA TERHADAP BIMBINGAN DAN KONSELING ISLAM
}

\author{
Suryadi \\ s2lazuvya@gmail.com \\ Institut Agama Islam Negeri (IAIN) Jember \\ Sukamto \\ Institut Agama Islam Negeri (IAIN) Jember \\ kamtotok80@gmail.com
}

\begin{abstract}
Thinking and looking for the argument for ma' rifat to Allah SWT is the first obligation for a Mukallaf (one who has received the burden of taklif). Knowing God means that someone also knows himself. Regarding knowing human self, there have actually been many theories that lead to this, the proof is that there are many theories about good personality that were sparked by thinkers from the west or by Islamic scholars. In this study, the researcheris nterested in discussing one personality theory that is very rarely discussed, namely personality theory according to Taqiyuddin An Nabhani especially his Islamic personality theory. The purpose of this study is as an additional reference and add Khazanah knowledge about human personality. Taqiyuddin An Nabhani is a contemporary cleric from the Palestinian area who has written any works both in figh and politics. This research is a qualitative study with a type of library research. Data analysis techniques used in this study are content analysis, namely by analyzing various sources of reference both primary and secondary. After researchers examine several sources, it can be concluded that according to Taqiyuddin An Nabhani, humans have two personality elements in themselves, namely the mindset ('aqliyah) and the attitude pattern (nafsiyah). Mindset is a method used in understanding or thinking about something. In other words, mindset is a method used to associate facts with information, or vice versa, based on a certain basis or several methods. While the attitude pattern is a method used by humans by linking the impulse of distribution (fulfillment) with mafahim (understanding) or the way used by humans to meet gharizah instinct and physical needs. a person can be said to have an Islamic personality if he has 'aqliyah Islamiyah (Islamic mindset) and nafsiyah Islamiyah (Islamic attitude pattern). If one of the two does not exist in a person then in fact he does not have an Islamic personality.
\end{abstract}

Keywords: Concept, Islamic Personality, Taqiyuddin An Nabhani 


\section{A. Pendahuluan}

Taqiyuddin An Nabhani adalah seorang ulama yang lahir pada sekitar awal abad 19 di desa Ijzim, selatan kota Haifa, wilayah Kiral Mahral. Beliau tumbuh dan besar di rumah yang sangat memperhatikan ilmu agama. Ayah beliau Syaikh Ibrahim An Nabhani, seorang Syeikh yang faqqih fid din. ${ }^{1}$ Dan sebagai tenaga pengajar ilmu syariah di Kementrian Pendidikan Palestina. Sementara ibu beliau juga menguasai beberapa cabang ilmu syariah, yang diperolehnya dari ayahnya, Syaikh Yususf An Nabhani, salah seorang diantara para ulama yang menonjol di Daulah Utsmaniyah. ${ }^{2}$

Keluarga an-Nabhani adalah keluarga mulia, yang memiliki kedudukan tinggi dalam ilmu pengetahuan dan agam Nasab keluarga beliau kembali pada keluarga besar (trah) anNabhani dari kabilah «h Hanajirah di Bi'r asSab'a. Banu (keturunan) Nabhan merupakan kepercayaan Bani Samak dari keturunan Lakhm ${ }^{3}$ yang tersebar di wilayah-wilayah Palestina. ${ }^{4}$

Syaikh Taqiyuddin An Nabhani mendapatkan erhatian dan pengawasan langsung dari kakeknya dari jalur ibunya, Syaikh Yusuf bin Ismail An Nabhani. Sungguh perkembangan keagamaan yang dialami Syaikh Taqiyuddin An Nabhani berpengaruh besar terhadap pembentukan kepribadiannya, orientasi dan pandangan keagamaannya. Beliau telah hafal al Qur'an di luar kepala sebelum beliau berumur 13 tahun.

\footnotetext{
1Sulistiawati dan Ahmad Fuad, "Konsep Kepemilikan Dalam Islam Studi Atas Pemikiran Syaikh Taqiyuddin an-Nabhani", Jurnal Syariah, Vol. V, No. 2, Oktober 2017, 24

2Taqiyuddin An Nabhani, Pilar-pilar Pengokoh Nafsiyah Islamiyah, (Jakarta: HTI Press, 2016), $X$

${ }^{3}$ Lakhm adalah Malik bin Adiy. Mereka memiliki bangsa dan suku yang banyak. Pada akhir ke2 Masehi sekelompok dari bani Lakhm tiba di Palestina bagian Selatan. Bani Lakhm memiliki kebanggaan-kebanggaan yang teragung, dan diantara yang terkenal adalah Tamin ad-Daroy ash-Shahaby. Muhammad Muhsin Rodhi, Hizb at-Tahrir: Tsafaqotuhu wal Manhajuhu fi Iqomah Daulah alkhilafah al-lslamiyyah, Terj. Muhammad Bajuri Romli Abu Wafa dengan judul Tsaqofah dan Metode Hizbut Tahrir dalam Mendirikan Negara Khilafah Islamiyyah (Baghdad: Departemen Pendidikan Tinggi dan Kajian Keilmuan Universitas Islam, 2008), 59

4Siti Jamilah, "Gerakan Hizbut Tahrir di Kota Pare-Pare (Membaca Pengaruh Pemikiran Taqiyuddin al-Nabhani)", Jurnal Diskursus Islam, Vol. 3, No. 1, Tahun 2015, 3
} 
Beliau banyak belajar ilmu dari kakeknya, sejak kecil kakeknya sering mengikutsertakannya dalam forum-forum diskusi fiqih maupun politik, sehingga terbentuklah pada dirinya jiwa-jiwa pemikir yang akhirnya bisa membuahkan banyak sekali karya-karya besar yang hingga kini masih banyak dipakai sebagai bahan rujukan dalam berbagai bidang keilmuan. Kejeniusan Syaikh Taqiyuddin ini tentu tidak ia dapatkan hanya dengan begitu saja melainkan dengan usaha yang luar biasa dan tentunya dengan menggunakan fungsi akal dengan sebaikbaiknya.

Allah SWT berfirman:

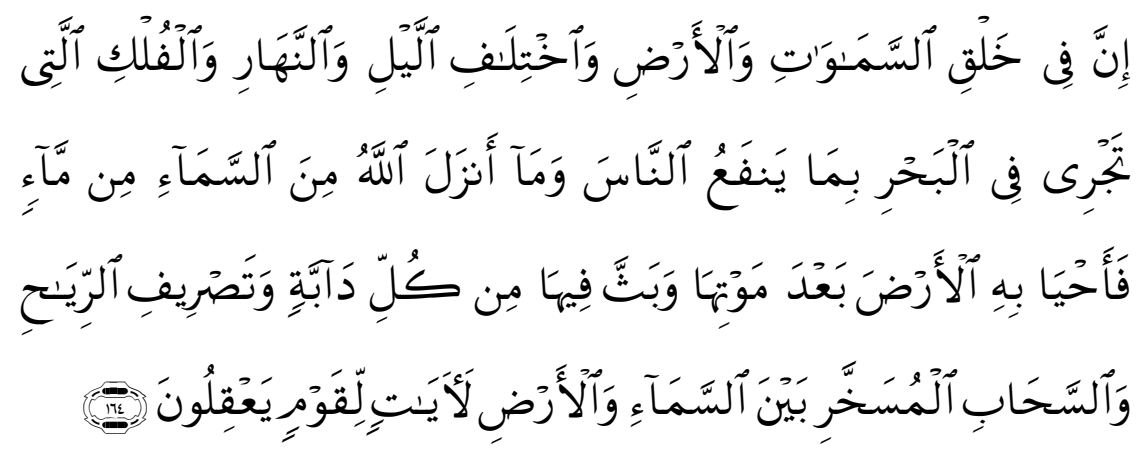

Artinya: "Sesungguhnya dalam penciptaan langit dan bumi, silih bergantinya malam dan siang, bahtera yang berlayar di laut membawa apa yang berguna bagi manusia, dan apa yang Allah turunkan dari langit berupa air, lalu dengan air itu Dia hidupkan bumi sesudah mati (kering)-nya dan Dia sebarkan di bumi itu segala jenis hewan, dan pengisaran angin dan awan yang dikendalikan antara langit dan bumi; sungguh (terdapat) tanda-tanda (keesaan dan kebesaran Allah) bagi kaum yang memikirkan" (QS. Al-Baqarah, 2: $164)^{5}$

Maha benar Allah dengan segala firman-Nya.Ayat diatas merupakan salah satu dari sekian banyak ayat di Al Qur'an yang mengajak manusia agar berpikir tentang alam semesta, manusia, kehidupan, Sang Khalik serta hakikat dari pencipta dan ciptaanNya. Allah SWT tidaklah menciptakan manusia begitu saja sebagaimana yang telah Allah sampaikan dalam ayat berikut:

${ }^{5}$ Via Al-Qur'an Indonesia http://quran-id.com 


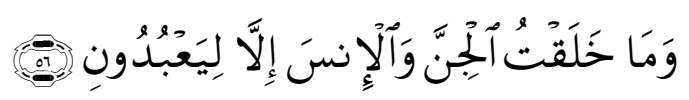

Artinya: "Aku tidak menciptakan jin dan manusia melainkan agar mereka beribadah kepada-Ku." (QS. Az-Zariyat, 51: 56)6

Bentuk pengabdian atau ibadah kepada Allah Swt secara umum dibagi menjadi dua bentuk ibadah, yakni ibadah khusus dan ibadah umum. ${ }^{7}$ Ibadah khusus, yaitu ibadah langsung kepada Allah Swt yang cara dan waktunya telah ditentukan oleh Allah sendiri sedangkan rinciannya dijelaskan oleh Rasulullah Saw, seperti ibadah shalat, puasa, zakat dan haji. Sedangkan ibadah umum adalah segalah bentuk amal saleh yang bermanfaat dan diridhoi oleh Allah Swt. Dan juga dalam ayat:

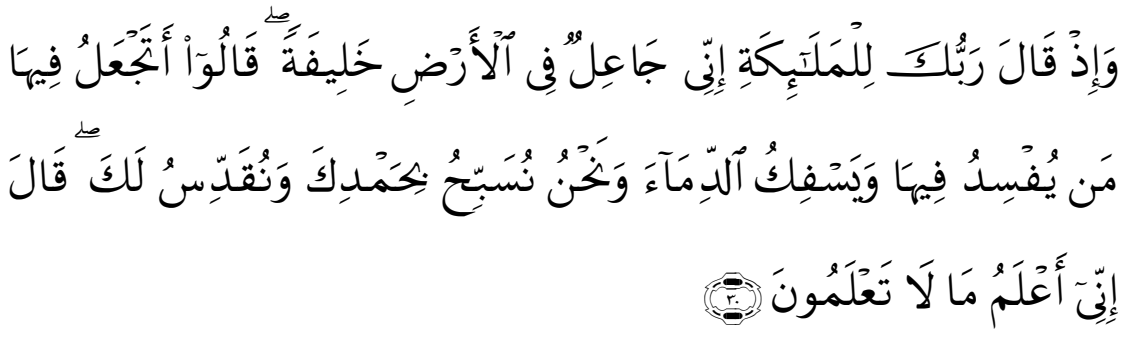

Artinya: "Dan (ingatlah) ketika Tuhanmu berfirman kepada para malaikat, Aku hendak menjadikan khalifah di bumi. Mereka berkata, Apakah Engkau hendak menjadikan orang yang merusak dan menumpahkan darah di sana, sedangkan kami bertasbih memuji-Mu dan menyucikan nama-Mu? Dia berfirman, Sungguh, Aku mengetahui apa yang tidak kamu ketahui."(QS. Al-Baqarah, 2:30) ${ }^{8}$

Pada ayat tersebut, disebutkan bahwa manusia diciptakan di muka bumi agar manusia dapat menjadi Khalifah dalam rangka untuk menegakkan hukum-hukum dan menerapkan ketetapan-ketetapan Allah Swt. Menurut Rasjidi dalam Ali, ${ }^{9}$ perkataan "menjadi Khalifah" dalam ayat tersebut mengandung makna bahwa Allah Swt menjadikan manusia wakil atau

${ }^{6}$ Ibid

7 Mohammad Daud Ali, Pendidikan Agama Islam, (Jakarta: Raja Grafindo Persada, 1998), h.13-14

8 Via Al-Qur'an Indonesia http://quran-id.com

9 Mohammad Daud Ali, Pendidikan Agama Islam, (Jakarta: Raja Grafindo Persada, 1998), h.14 
pemegang kekuasaan-Nya mengurus dunia dengan jalan melaksanakan segala yang diridhoi-Nya dimuka bumi ini. Dari uraian di atas dapat dipahami bahwa tujuan manusia diciptakan oleh Allah Swt semata-mata hanya untuk beribadah dengan kata lain manusia diperintahkan untuk senantiasa terikat dengan aturan Allah Swt dalam segala aspek kehidupan.

Tentu untuk menjalankan peran tersebut tidaklah mudah. Oleh karena itu Allah SWT beri keistimewaan pada manusia yang tidak Allah berikan pada makhluk-Nya yang lain, yakni keistimewaan berupa akal. Akal mempunyai peran yang sangat signifikan bagi kehidupan manusia.Dengan adanya akal manusia dapat membedakan mana yang baik dan buruk, mana yang terpuji dan tercela, mana yang haq dan mana yang bathil.

Dengan akal pula manusia bisa mulia derajat dan kehidupannya, namun akal sebenarnya bisa mengantarkan manusia pada tempat yang serendah-rendahnya apabila ia tidak dipakai untuk memahami hakikat kehidupan yang baik. Seperti yang Allah SWT telah firmankan:

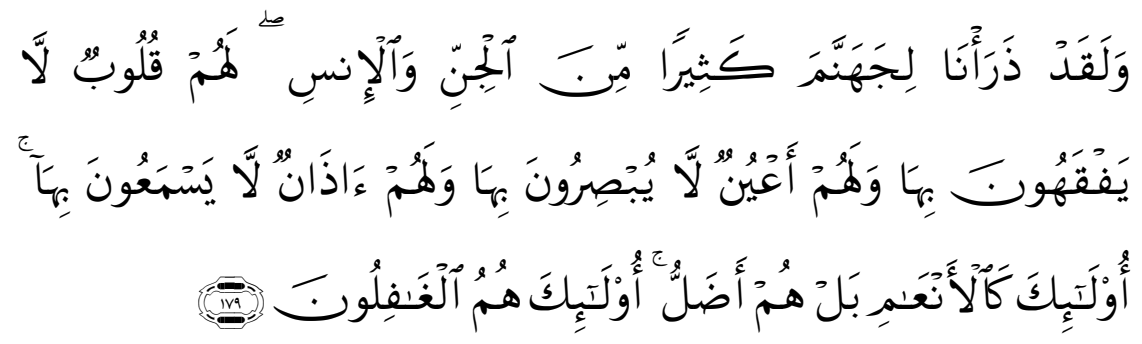

Artinya: "Dan sungguh, akan Kami isi Neraka Jahanam banyak dari kalangan jin dan manusia. Mereka memiliki hati, tetapi tidak dipergunakannya untuk memahami (ayat-ayat Allah) dan mereka memiliki mata (tetapi) tidak dipergunakannya untuk melihat (tanda-tanda kekuasaan Allah), dan mereka mempunyai telinga (tetapi) tidak dipergunakannya untuk mendengarkan (ayat-ayat Allah).Mereka seperti hewan ternak, bahkan lebih sesat lagi.Mereka itulah orang-orang yang lengah."(QS. Al-A'raf, 7: 179) ${ }^{10}$

10 Via Al-Qur'an Indonesia http:/ / quran-id.com 
Oleh karena itu sesungguhnya wajib bagi manusia untuk senantiasa menggunakan akal nya untuk memikirkan dan memahami hakikat dirinya, darimana dia berasal; untuk apa dia hidup; dan akan kemana dia setelah kehidupan ini. Dengan begitu dia akan memahami dirinya dan juga penciptanya. Imam Syafi'i berkata:

"Ketahuilah bahwa kewajiban pertama bagi seorang Mukallaf adalah berpikir dan mencari dalil untuk ma'rifat kepada Allah Ta'ala.Arti berpikir adalah melakukan penalaran dan perenungan qalbu dalam kondisi orang yang berpikir tersebut dituntut untuk ma'rifat kepada Allah. Dengan cara seperti itu, ia bisa sampai pada ma'rifat terhadap hal-hal yang ghaib dari pengamatannya dengan indera dan ini merupakan suatu keharusan. Hal ini merupakan kewajiban dalam bidang ushuludin"11

Jadi dengan memahami diri dan hakikat penciptaan (untuk beribadah kepada Allah SWT) serta mamahami eksistensi dan peran Pencipta (sebagai Sang Khalik wa Mudabbir yang wajib disembah) maka hidup manusia akan penuh dengan cahaya terang dan ia akan berjalan dengan terarah sebagaimana musafir yang sedang safar di siang hari dengan perbekalan yang cukup sehingga ia akan sampai pada tujuannya dengan selamat.

Manusia diciptakan oleh Allah SWT, sebagai makhluk yang paling sempurna diantara makhluk Allah lainnya. Sudah sejatinya memiliki kepribadian yang baik. Yang artinya manusia harus memiliki daya berfikir, beperilaku sesuai dengan akidah Islam. Namun faktanya, meski seorang muslim belum tentu jaminan ia memiliki kepribadian muslim. Jika kita melihat kondisi umat Islam di Indonesia, tergambar sangat jelas betapa merosotnya sebagian Islami sebagai umat Islam. ${ }^{12}$

Realita yang paling buruk, bisa kita lihat melalui media sosial, atau bahkan di sekitar lingkungan kita. Kerusakan moral banyak terjadi pada kaum muda sebagai generasi penerus bangsa. Keruskan moral yang saat ini suda menjadi pandemi

11 Asy Syafi'i dalam Arief B. Iskandar, Materi Dasar Islam Islam Mulai Akar Hingga Daunnya, (Bogor: Al Azhar Press, 2015), h. 2

12 Anton Widodo, Fathur Rohman, Konsep Jiwa Yang Tenang Menurut Surta Al Fajr Ayat 27-30 (Perspektif Bimbingan Penyuluhan Islam), Al-Irsyad: Jurnal Bimbingan Penyuluhan Islam,Vol.1. N0.2 Juli-Desember 2019 h. 5-7 
diantaranya adalah sifat hedonisme, free sex, pergaulan bebas, budaya pacaran serta budaya korupsi dinegeri ini. ${ }^{13}$

Untuk mamahami eksistensi dan peran Pencipta sebagai Sang Khalik wa Mudabbir yang wajib disembah maka hal membutuhkan pembahasan yang mendalam dan hal ini tidak akan dibahas di dalam penelitian ini karena untuk menjaga agar pembahasan penelitian ini tetap fokus pada pembahasan utama yaitu konsep kepribadian islam menurut Taqiyuddin An Nabhani.

Adapun untuk memahami hakikat manusia salah satunya dengan cara memahami konsep kepribadian manusia itu sendiri. Ada banyak sekali tokoh-tokoh barat maupun tokoh Muslim yang memiliki konsep tersendiri tentang kepribadian manusia seperti Sigmund Freud, Carl G. Jung, Imam Al Ghazali, Alfred Adler, B. F. Skinner, Albert Bandura, Abraham Maslow, Carl Rogers dan masih banyak lagi tokoh-tokoh lainnya. Menurut tokoh barat kepribadian itu bersal dari kata persona yang artinya adalah "topeng" ${ }^{14}$

Sigmund Freud dikenal dengan teori Psikoanalisis Klasiknya yang mengatakan bahwa manusia memiliki tiga struktur kepribadian yaitu id (das es), ego (das ich) dan super ego (das ueber ich).15 Carl Rogers dikenal dengan teoriclient center/berpusat pada diri dengan anggapan bahwa manusia adalah makhluk yang bertanggung jawab terhadap diri sendiri dan memiliki kemampuan untuk memutuskan apa yang paling tepat bagi dirinya. Cara pandang ini sangat berlawanan dengan aliran psikoanalisis ataupun behaviorisme yang mendudukkan manusia sebagai korban dari masa lalu atau sangat dipengaruhi oleh lingkungannya. ${ }^{16}$

${ }^{13 G u s ~ D i n ~ E l-H a q ~ I w a n d i, ~ " M e t o d e ~ P e m b e n t u k a n ~ K e p r i b a d i a n ~ I s l a m i ~}$ Menurut Syaikh Taqiyuddin An-Nabhani" Al-Fikra: Jurnal Ilmiah Keislaman, Vol 17, No 2, Juli-Desember 2018, 279

${ }^{14}$ Agus Silahudin, "Perbandingan Konsep Kepribadian Menurut Barat dan Islam" Al-Fikra: Jurnal Ilmiah Keislaman, Vol. 17, No 2, Juli-Desember 2018, 249

15 Dede Rahmat Hidayat, Teori dan Aplikasi Psikologi Kepribadian Dalam Konseling, (Bogor: Ghalia Indonesia, 2015), h. 27

16Ibid, h. 175 
Setiap tokoh yang mencetuskan teori-teori kepribadian memiliki cara pandang yang khas dan berbeda-beda namun juga saling berkaitan antara satu dengan yang lain. Pada setiap teori tentu dapat diambil untuk kemudian diaplikasikan dalam proses konseling. Pada kesempatan kali ini peneliti tertarik untuk membahas salah satu teori kepribadian yang jarang dibahas sebelumnya yaitu "Konsep Kepribadian Islam Menurut Taqiyuddin An Nabhani".

Bila konsep kepribadian yang banyak dibahas selama ini adalah konsep kepribadian secara umum, maka pada kesempatan ini peneliti mengkhususkan pada pembahasan konsep kepribadian Islam menurut Taqiyuddin An Nabhani dengan harapan penelitian ini dapat memberikan manfaat baik bagi para konselor ataupun pihak-pihak lainnya dalam bidang terapan maupun bidang akademik.

\section{B. Metodologi}

Ditinjau dari jenisnya, penelitian ini bersifat literatur, termasuk pada jenis penelitian pustaka (library research). Penelitian kepustakaan (library research) yaitu penelitian yang pengumpulan datanya dilakukan dengan menghimpun data dari berbagai literatur. Literatur yang diteliti tidak terbatas pada buku-buku tetapi dapat juga berupa bahan-bahan dokumentasi, majalah, jurnal, dan surat kabar. Penekanan penelitian kepustakaan adalah ingin menemukan berbagai teori, hukum, dalil, prinsip, pendapat, gagasan dan lain-lain yang dapat dipakai untuk menganaliis dan memecahkan masalah yang diteliti ${ }^{17}$.

Adapun pendekatan yang digunakan dalam penelitian ini adalah pendekatan kualitatif, yaitu dengan menekankan analisisnya pada proses penyimpulan komparasi serta pada analisis terhadap dinamika hubungan fenomena yang diamati dengan menggunakan logika ilmiah. ${ }^{18}$

17Sarjono. DD., Panduan Penulisan Skripsi, (Yogyakarta: Jurusan Pendidikan Agama Islam, 2008), h. 20

18 Saifuddin Azmar, Metode Penelitian, (Yogyakarta: Pustaka Pelajar, 2001), h. 5 
Dalam penelitian kepustakaan (library research) ini, sumber data yang merupakan bahan tertulis terdiri atas sumber data primer dan sumber data sekunder. Data primer dalam penelitian ini diambil dari buku-buku karangan Taqiyuddin An Nabhani yang yang berkaitan dengan konsep kepribadian Islam seperti من مقومات النفسية الإسلامية (Pilar-pilar Pengokoh Nafsiyah Islamiyah) dan الشخصية الإسلامية الإنسية (Kepribadian Islam) yang diterjemahkan oleh Zakia Ahmad. Serta buku-buku karya Taqiyuddin An Nabhani yang lainnya. Adapun sumber data sekunder adalah data yang diperoleh lewat pihak lain, tidak langsung diperoleh oleh peneliti dari subyek penelitiannya. ${ }^{19}$ Dengan kata lain, data sekunder adalah data pendukung dari data utama atau data primer. Data sekunder dari penelitian ini diambil dari berbagai sumber seperti buku, artikel.

\section{Hasil dan Pembahasan}

Kepribadian manusia menurut Taqiyuddin An Nabhani terdiri dari 'aqliyah (pola pikir) dan nafsiyah (pola sikap). Kepribadian tidak ada kaitannya dengan bentuk tubuh, asesori dan sejenisnya.Semua itu hanya (penampakan) kulit luar belaka. 20 'Aqliyah (pola pikir) adalah cara yang digunakan dalam memahami atau memikirkan sesuatu. Dengan ungkapan lain 'aqliyah (pola pikir) adalah cara yang digunakan untuk mengaitkan fakta dengan ma'lumat, atau ma'lumat dengan fakta, berdasarkan suatu landasan atau beberapa kaedah tertentu. Dari sinilah munculnya perbedaan pola pikir ('aqliyah), seperti pola pikir islami, sosialis, kapitalis, marxis dan pola pikir lainnya. ${ }^{21}$

\begin{tabular}{|l|l|l|l|}
\hline \multicolumn{1}{|c|}{ Aspek } & \multicolumn{1}{|c|}{ Islam } & \multicolumn{1}{|c|}{ Kapitalis } & \multicolumn{1}{c|}{$\begin{array}{c}\text { Sosialis- } \\
\text { Komunis }\end{array}$} \\
\hline Dasar & Lailaha illallah, & Memisahkan & Materialism \\
Akidah & menyatukan & agama dari & dan evolusi, \\
& antara aturan & kehidupan & menolak \\
& beserta hukum & masyarakat & keberadaan \\
& Alah dengan & dan negara & agama. \\
\hline
\end{tabular}

19 Saifuddin Azwar, Metode Penelitian, (Yogyakarta: Pustaka Pelajar, 2009), 91.

20 Taqiyuddin An Nabhani, Syakhshiyah Islam kepribadian Islam, jilid 1, terjemah. zakia Ahmad, (Bogor:Pustaka Thariqul Izzah, 2003),1

${ }^{21}$ Ibid, h. 3 


\begin{tabular}{|c|c|c|c|}
\hline & khidupan & & \\
\hline $\begin{array}{l}\text { Pembuat } \\
\text { Hukum dan } \\
\text { Aturan }\end{array}$ & $\begin{array}{l}\text { Allah lewat } \\
\text { wahyu, akal } \\
\text { berfungsi } \\
\text { menggali fakta } \\
\text { dan memahami } \\
\text { hukum dan } \\
\text { wahyu }\end{array}$ & $\begin{array}{l}\text { Manusia } \\
\text { membuat } \\
\text { hukum sendiri } \\
\text { melalui fakta } \\
\text { yang dilihatnya }\end{array}$ & $\begin{array}{l}\text { Manusia } \\
\text { membuat } \\
\text { sistem aturan } \\
\text { dan hukum } \\
\text { sendiri dari } \\
\text { alat-alat } \\
\text { produksi }\end{array}$ \\
\hline Fokus & $\begin{array}{l}\text { Individu } \\
\text { merupakan } \\
\text { salah satu } \\
\text { anggota } \\
\text { masyarakat. } \\
\text { Individu } \\
\text { diperhatikan } \\
\text { demi kebaikan } \\
\text { masyarakat, } \\
\text { dan } \\
\text { masyarakat } \\
\text { diperhatikan } \\
\text { demi kebaikan } \\
\text { individu. }\end{array}$ & $\begin{array}{l}\text { Individu } \\
\text { adalah } \\
\text { segalanya. } \\
\text { Masyarakat } \\
\text { merupakan } \\
\text { kumpulan dari } \\
\text { individu }\end{array}$ & $\begin{array}{l}\text { Negara diatas } \\
\text { segalanya, } \\
\text { individu } \\
\text { merupakan } \\
\text { komponen } \\
\text { dari } \\
\text { masyarakat } \\
\text { yang berupa } \\
\text { sumber daya } \\
\text { manusia dan } \\
\text { lainnya. }\end{array}$ \\
\hline $\begin{array}{l}\text { Ikatan } \\
\text { Prilaku }\end{array}$ & $\begin{array}{l}\text { Seluruh } \\
\text { perilaku terkait } \\
\text { dengan syara'. } \\
\text { Perilaku bebas } \\
\text { dilakukan bila } \\
\text { sesuai dengan } \\
\text { hukum syara' }\end{array}$ & $\begin{array}{l}\text { Serba bebas } \\
\text { dengan } \\
\text { masalah } \\
\text { akidah, } \\
\text { pendapat, dan } \\
\text { kebebasan } \\
\text { pribadi }\end{array}$ & $\begin{array}{l}\text { Dalam prilaku } \\
\text { bebas namun, } \\
\text { tdak ada } \\
\text { kebebasan } \\
\text { dalam akidah } \\
\text { dan } \\
\text { kepemilikan } \\
\end{array}$ \\
\hline $\begin{array}{l}\text { Penerapan } \\
\text { Hukum }\end{array}$ & $\begin{array}{l}\text { Atas } \\
\text { ketaqwaan } \\
\text { individu, } \\
\text { control } \\
\text { masyarakat, } \\
\text { dan penerapan } \\
\text { Negara. }\end{array}$ & $\begin{array}{l}\text { Terserah } \\
\text { Individu }\end{array}$ & $\begin{array}{l}\text { Tangan besi } \\
\text { dari Negara }\end{array}$ \\
\hline
\end{tabular}

Dari tabel diatas dapat ditarik kesimpulan bahwa: Pola pikir pada manusia pasti melibatkan fungsi akal dan Taqiyuddin An Nabhani mengartikan akal adalah pemindahan penginderaan terhadap fakta melalui panca indera ke dalam otak yang disertai 
adanya informasi-informasi terdahulu yang akan digunakan untuk menafsirkan fakta tersebut. ${ }^{22}$

Pola pikir pada setiap manusia akan menghasilkan mafahim (pemahaman). Dan apa yang dihasilkan oleh mafahim (pemahaman) adalah sebagai penentu tingkah laku manusia terhadap fakta yang ditemuinya. Juga sebagai penentu corak kecenderungan manusia terhadap fakta tadi, berupa (sikap) menerima atau menolak. Kadangkala dapat membentuk kecenderungan dan perasaan tertentu. ${ }^{23}$

Unsur kepribadian yang kedua menurut Taqiyuddin An Nabhani adalah nafsiyah (Pola Sikap). Nafsiyah (Pola Sikap) adalah cara yang digunakan manusia dengan mengaitkan dorongan penyaluran (pemenuhan) nya dengan mafahim (pemahaman)atau cara yang digunakan oleh manusia untuk memenuhi gharizah (naluri) dan kebutuhan jasmani.

Mengenai gharizah (naluri) atau kebutuhan jasmani pada manusia, Taqiyuddin An Nabhani menjelaskan sebagaimana berikut:

"Bahwa Allah SWT telah menciptakan pada manusia potensi kehidupan thaqah hayawiyyah (potensi kehidupan), yaitu potensi yang juga diciptakan Allah SWT pada yang lainnya. ${ }^{24}$ Seperti halnya pada benda-benda yang telah diciptakan khasiat-khasiatnya, maka pada diri manusia telah diciptakan pula berbagai Gharizah (naluri) serta hajatul 'udhowiyah (kebutuhan jasmani)."25

\section{Hajat 'udhowiyyah (kebutuhan jasmani)}

Allah telah menjadikan pada masing-masing diri manusia hajat 'udhowiyyah (kebutuhan jasmani). Dalam kebutuhan jasmani diciptakan pula khasiat-khasiat (potensi-potensi) seperti, lapar, haus dan sebagainya. Semua khasiat (potensi) ini dijadikan Allah

22 Taqiyuddin An Nabhani ,Hakekat Berpikir, penj. Taqiyuddin As Siba'i, (Bogor: Pustaka Thariqul Izzah, 2003), h. 26

23 Taqiyuddin An Nabhani, Syakhshiyah Islam kepribadian Islam, jilid 1, terjemah zakia Ahmad, (Bogor:Pustaka Thariqul Izzah, 2003), h. 3

24 Taqiyuddin An Nabhani, Sistem Pergaulan Dalam Islam, (Jakarta Selatan: HTI Press, 2015). h. 21

25 Taqiyuddin An Nabhani, Peraturan Hidup Dalam Islam, penj. Abu Amin, (Jakarta Selatan: HTI Press, 2016), h. 35 
SWT bersifat baku sesuai dengan sunnatul wujud (peraturan alam yang ditetapan Allah SWT) ${ }^{26}$

Kebutuhan jasmani ini merupakan kebutuhan dasar yang timbul akibat kerja struktur organ tubuh manusia. Jika kebutuhan dasar tersebut tidak dipenuhi, struktur organ tubuhnya akan mengalami gangguan dan bisa mengakibatkan kerusakan. Sebagai contoh, jika tubuh manusia kekurangan air, maka kerja organ tubuhnya akan mengalami gangguan yang kemudian akan menyebabkan penyakit. ${ }^{27}$

Sesungguhnya kebutuhan jasmani secara alamiah akan menuntut pemuasan karena dorongan internal, tanpa memerlukan rangsangan eksternal, meskipun rangsangan eksternal juga dapat membangkitkan kebutuhan jasmani pada saat manusia kelaparan. ${ }^{28}$ Tuntutan pemuasan dari kebutuhan jasmani tidak akan hilang pada saat kebutuhan jasmani itu menuntut pemuasan. Bahkan tuntutan itu akan terus ada sampai tuntutannya dipuaskan. ${ }^{29}$

\section{Ghara'iz (naluri-naluri)}

Ghara'iz (naluri-naluri) adalah bentuk jamak dari kata gharizah yang artinya naluri.Naluri atau insting adalah potensi pada diri manusia untuk cenderung terhadap sesuatu (benda) dan perbuatan.Juga dengan potensi ini menusia terdorong untuk meninggalkan sesuatu dan perbuatan.Semuanya hanyalah demi memenuhi kebutuhan internal. ${ }^{30}$

Naluri adalah potensi alami yang ada pada diri manusia untuk menjaga dan melestarikan kelangsungan hidupnya, untuk menjaga spesiesnya, dan agar mendapat petunjuk mengenai adanya Al khaliq (Sang Pencipta).Naluri itu tidak bisa terindera dengan indera secara langsung.Namun akal mampu mengindera eksistensinya melalui penampakan-penampakannya. ${ }^{31}$

26Ibid

27 Hafizh Abdurrahman, Diskursus Islam Politik dan Spiritual, (Bogor: Al Azhar Press, 2010), h. 48

28 Taqiyuddin An Nabhani, Sistem Pergaulan Dalam Islam, (Jakarta Selatan: HTI Press, 2015). h. 31

${ }^{29}$ Ibid, h. 32

30 Muhammad Husain Abdullah, Mafahim Islamiyah, (Bangil: al Izzah, 2002). h. 13

31Ibid, h. 14 
Ada banyak pendapat mengenai jenis-jenis naluri pada manusia seperti rasa takut, keibuan, kebapakan, kasih sayang, ingin memiliki, ingin tahu, dan masih banyak lagi. Namun Menurut Taqiyuddin An Nabhani semua itu hanyalah penampakan atau menifestasi dari hanya tiga jenis naluri, yaitu:

\section{a) Gharizah al-baqa' (Naluri mempertahankan diri)}

Adapun wujud naluri mempertahankan diri ini terlihat saat manusia mempertahankan dirinya, membela tanah air dan tempat kelahirannya, keinginan memimpin, menguasai dan mendominasi orang lain, dan sebagainya. ${ }^{22}$ Setiap manusia mempunyai keinginan untuk memiliki, merasa takut, berani, senang berkelompok dan berbagai aktifitas sejenis, yang dilakukan dalam rangka mempertahankan diri.Rasa takut ini bukanlah naluri; keinginan untuk memiliki juga bukan naluri; berani bukan naluri; senang berkelopok bukan naluri; dan seterusnya.Semua ini hanyalah manifestasi atau penampakan dari Gharizah al-baqa' (naluri mempertahankan diri). ${ }^{33}$

\section{b) Gharizah al-nau' (Naluri melestarikan keturunan)}

Adapun tujuan dari penciptaan naluri ini adalah untuk melestarikan keturunan. ${ }^{34}$ Namun, sekalipun naluri melestarikan jenis dapat dipuaskan oleh manusia dengan sesama jenisnya pria dengan pria atau wanita dengan wanita- dan dapat pula dipuaskan dengan binantang atau dengan sarana-sarana lain, tetapi cara semacam itu tidak akan mungkin dapat mewujudkan tujuan diciptakannya naluri tersebut kecuali pada satu kondisi saja, yaitu pemenuhan naluri tersebut oleh seorang wanita dengan seorang pria atau sebaliknya. ${ }^{35}$

32 Hafizh Abdurrahman, Nizham Fi Al Islam, (Bogor: Al Azhar Fresh Zone Publishing, 2015), h. 89

33 Muhammad Muhsin Rodhi, Tsaqofah Dan Metode Hizbut Tahrir Dalam Mendirikan Negara Khilafah, penj. Muhammad Bajuri \& Romli Abu Wafa, (Bogor: Al Azhar Press, 2012), h.226

34 Taqiyuddin An Nabhani, Sistem Pergaulan Dalam Islam, (Jakarta Selatan: HTI Press, 2015), h. 28

$35 \mathrm{Ibid}$, h. 22 
c) Gharizah al-tadayyun (Naluri beragama)

Gharizah al-tadayyun (naluri beragama) yang membangkitkannya adalah berpikir tentang ayat-ayat Allah SWT, hari kiamat, atau sesuatu yang berkolerasi dengannya, atau melihat keindahan ciptaan Allah dilangit dan di bumi atau yang berkolerasi dengannya. ${ }^{36}$ Adapun manifestasi atau wujud dari naluri ini adalah menyucikan terhadap sesuatu yang diyakini sebagai Sang Pencipta yang mengatur segala sesuatu, atau sesuatu yang diilustrasikan sebagai manifestasi Sang Pencipta. Terkadang takdis nampak dengan manifestasi yang sebenarnya, maka menjadi ibadah, terkadang pula nampak dengan gambaran paling minim yaitu berupa penghormatan dan pengagungan. ${ }^{37}$

Menurut Abdullah yang dikutip oleh Saktiyono, mengenai segala sesuatu yang dapat memenuhi kebutuhan jasmaninya seperti; makan, minum, bernafas, tidur, dan buang air. Hal tersebut merupakan pertalian antara kebutuhan jasmani dan naluri mempertahankan diri, karena ditujukan untuk menjaga kelangsungan hidup serta melaksanakan fungsi-fungsi alaminya. ${ }^{38}$ Apabla aktivitas makan misalnya, datang dari dalam tubuhnya karen aorgan-organ tubuhnya memerlukan zat-zat dalam makanan, maka pemenuhannya merupakan kebutuhan jasmani. Namun, apabila aktivitas maka merupakan hasil kecintaannya pada makanan (memikirkan atau melihat bentuk makanan yang menggiurkan), sedangkan tubuhnya tidak membutuhkan zat-zat dalam makanan, maka pemenuhannya merupakan menifestasi dari naluri. Perbedaan antara kebutuhan jasmani dan dan naluri-naluri diuraikan dalam tabel berikut ini:

\begin{tabular}{|l|l|l|}
\hline \multicolumn{1}{|c|}{ Aspek } & \multicolumn{1}{c|}{ Kebutuhan Jasmani } & \multicolumn{1}{c|}{ Naluri-naluri } \\
\hline Stimulus & $\begin{array}{l}\text { Bersifat internal, yaitu } \\
\text { muncul akibat kerja } \\
\text { homeostasis jaringan } \\
\text { tubuh }\end{array}$ & $\begin{array}{l}\text { Bersifat internal } \\
\text { dan/eksternal, yaitu } \\
\text { muncul akibat } \\
\text { pemikiran dan/atau } \\
\text { fakta yang terindera. }\end{array}$ \\
\hline
\end{tabular}

36 Muhammad Muhammad Ismail, Refreshing Pemikiran Islam, (Bangil: al Izzah, 2004). h. 17

37Ibid, h. 18

38B. Purwoko Saktiyono, psikologi Islami, (Bandung: Saktitoyono Wordpress, 2012), 40. 


\begin{tabular}{|l|l|l|}
\hline Tuntunan & Menuntut pemenuhan & Menurut pemenuhan \\
pemenuhan & secara pasti, apabila & saja, apabila tidak \\
& tidak dipenuhi akan & dipenuhi akan \\
& mengakibatkan & menimbulkan \\
& kerusakan tubuh atau & perasaan gelisah dan \\
& mengantarkan pada & tidak mengantarkan \\
& kematian. & pada kematian. \\
\hline
\end{tabular}

Menurut Taqiyuddin An Nabhani apabila naluri manusia bangkit, maka ia akan menuntut pemuasan. Begitupun sebaliknya, jika naluri itu tidak bangkit, ia tidak menuntut pemuasan. Jika naluri menuntut pemuasan, naluri itu akan mendorong manusia untuk mewujudkan pemuasannya. Jika belum berhasil mewujudkan pemuasan, manusia akan gelisah selama naluri tersebut masih bergejolak. Setelah gejolak naluri tersebut reda, rasa gelisah itupun akan hilang. ${ }^{39}$

Tiadanya pemuasan naluri tidak akan menimbulkan kematian dan gangguan, baik gangguan fisik, jiwa, maupun akal. Naluri yang tidak terpuaskan hanya akan mengakibatkan kepedihan dan kegelisahan. Dari fakta ini, pemuasan naluri bukanlah sesuatu keharusan sebagaimana pemuasan kebutuhankebutuhan jasmani. Pemuasan naluri tidak lain hanya untuk mendapatkan ketenangan dan ketenteraman.

Mengenai faktor-faktor yang dapat membangkitkan naluri Taqiyuddin An Nabhani menyebutkan ada dua macam, yaitu:

(1) Fakta yang dapat diindera;

(2) Pikiran yang dapat mengundang makna-makna (bayangan-bayangan dalam benak). ${ }^{40}$

Jika salah satu dari kedua faktor itu tidak ada, naluri tidak akan bergejolak. Sebab, gejolak naluri bukan faktor internal, sebagaimana kebutuhan jasmani, melainkan karena faktor eksternal, yaitu dari fakta-fakta yang terindera dan pikiran yang dihadirkan.Fakta ini berlaku untuk semua macam naluri, yaitu naluri mempertahankan diri (gharizah al-baqa'), naluri beragama (gharizah at-tadayyun), dan naluri melestarikan keturunan

39 Taqiyuddin An Nabhani, Sistem Pergaulan Dalam Islam, (Jakarta Selatan: HTI Press, 2015). h. 27

${ }^{40}$ Taqiyuddin An Nabhani, Sistem Pergaulan Dalam Islam, (Jakarta Selatan: HTI Press, 2015), 27 
(gharizah an-naw'). Tidak ada perbedaan antara yang satu dengan yang lainnya.Bahkan manusia dapat mengatur kemunculannya, atau mampu mencegah bangkitnya naluri ini kecuali yang mengarah pada tujuan melestarikan keturunan. ${ }^{41}$

Menurut Taqiyuddin An Nabhani klaim orang-orang Barat dan orang-orang Komunis bahwa pengekangan naluri seksual pada pria dan wanita akan mengakibatkan berbagai penyakit fisik, psikis, maupun akal, adalah tidak benar dan hanya ilusi yang bertentangan dengan kenyataan. Sebab, ada perbedaan antara naluri manusia dan kebutuhan jasmaninya dari segi pemuasannya. ${ }^{42}$

Kebutuhan jasmani seperti makan, minum, dan buang hajat, menuntut pemuasan secara pasti. Kebutuhan-kebutuhan tersebut, jika tidak dipenuhi, akan mengakibatkan bahaya yang dapat menimbulkan kematian. Namun Sebaliknya, naluri manusia seperti naluri mempertahanan diri (gharizah al-baqa'), naluri beragama (gharizah at-tadayyun), dan naluri melestarikan keturunan (gharizah an-naw'), tidaklah menuntut pemuasan secara pasti. 43

Apabila naluri-naluri tersebut tidak dipenuhi, maka tidak akan menimbulkan bahaya terhadap fisik, jiwa, maupun akal manusia. Yang mungkin terjadi hanyalah kegelisahan dan kepedihan saja. Buktinya, adakalanya seseorang seumur hidupnya tidak memuaskan sebagian naluri tersebut, ternyata ia tidak mengalami bahaya apapun.

Bukti lainnya adalah bahwa apa yang diklaim orang-orang Barat dan orang-orang Komunis tentang munculnya berbagai gangguan atau penyakit fisik, psikis maupu akal, ternyata tidak terjadi pada setiap orang ketika ia tidak memuaskan naluri seksualnya. Gangguan itu hanya terjadi pada sebagian individu tertentu.Kenyataan ini menujukkan bahwa gangguan akibat tiadanya pemuasan tersebut tidaklah terjadi secara alami sebagai fitrah manusia.Selanjutnya Taqiyuddin An Nabhani menyebutkan bahwa gangguan itu terjadi karena sebab-sebab lain,

41 Ibid, h. 28

42 Taqiyuddin An Nabhani, Sistem Pergaulan Dalam Islam, (Jakarta Selatan: HTI Press, 2015), h. 30

${ }^{43} \mathrm{Ibid}$, h. 31 
bukan karena pengekangan. Sebab kalau memang itu terjadi karena pengekangan, gangguan tersebut pasti akan terjadi secara alami sebagai suatu fitrah pada setiap manusia, setiap kali ada pengekangan. Padahal kenyataannya gangguan tersebut tidak pernah terjadi.Merekapun sebenarnya mengakui bahwa gangguan itu, secara fitrah, tidak terjadi sebagai akibat pengekangan terhadap naluri seksualnya.Karena itu, gangguan yang terjadi pada individu-individu tertentu disebabkan oleh faktor-faktor lain, bukan karena pengekangan. ${ }^{44}$

Kenyataan bahwa faktor yang bisa merangsang naluri adalah faktor eksternal ini berlaku pada seluruh jenis naluri pada manusia, tak ada bedanya antara naluri mempertahanan diri (gharizah al-baqa'), naluri beragama (gharizah at-tadayyun), dan naluri melestarikan keturunan (gharizah an-naw'), dengan seluruh manifestasinya. ${ }^{45}$

Sebagai contoh, apabila dihadapan seseorang terdapat sesuatu yang dapat membangkitkan salah satu nalurinya, maka nalurinya akan bergejolak dan menuntut pemuasan. Namun sebaliknya apabila orang itu menjauhkan diri dari faktor-faktor yang dapat membangkitkan nalurinya, atau menyibukkan diri dengan sesuatu yang dapat mengalahkan gejolak naluri tersebut, maka tuntutan pemuasan itu akan hilang dan manusia akan kembali tenang.

Menurut Taqiyuddin An Nabhani bagaimana seseorang memenuhi hajatul 'udhowiyah (kebutuhan jasmani) dan ghara'iz (naluri-naluri)nya tergantung pada 'aqliyah (pola pikir)dan nafsiyah (pola sikap) nya. Seseorang baru bisa dikatakan berkepribadian Islam (Syakhshiyah Islam) ketika ia memiliki 'aqliyah (pola pikir)Islam dan nafsiyah (pola sikap) Islam secara bersamaan. 46

44Taqiyuddin An Nabhani, Sistem Pergaulan dalam Islam, (Jakarta Selatan: HTI Press, 2015), h. 31

45Taqiyuddin An Nabhani, Sistem Pergaulan dalam Islam, (Jakarta Selatan: HTI Press, 2015), h. 32

46Taqiyuddin An Nabhani, Sistem Pergaulan dalam Islam, (Jakarta Selatan: HTI Press, 2015), h. 7 


\section{1. 'Aqliyah Islamiyah (Pola Pikir Islam)}

'Aqliyah (pola pikir)Islam adalah berpikir berdasarkan Islam, yaitu menjadikan Islam satu-satunya tolak ukur umum terhadap seluruh pemikiran tentang kehidupan.Jadi, bukan sekedar untuk mengetahui atau untuk (kepuasan berpikir) seorang intelek.Selama seseorang mejadikan Islam sebagai tolak ukur atas seluruh pemikirannya secara praktis dan secara riil, berarti dia telah memiliki 'aqliyah (pola pikir) Islam.

Ketika seseorang memikirkan sesuatu untuk mengeluarkan keputusan hukum terhadapnya dengan menyandar kepada akidah Islam, maka 'aqliyah (pola pikir)nya merupakan 'aqliyah Islamiyah (pola pikir Islami). Jika tidak seperti itu, maka 'aqliyah(pola pikir)nya merupakan 'aqliyah (pola pikir) yang lain. ${ }^{47}$

Sedangkan kekuatan sendiri, adalah kekuatan yang digunakan oleh manusia untuk menghukumi sesuatu. Atau lebih tepatnya adalah kemampuan untuk menghukumi realitas (fakta) tertentu, baik yang berkaitan dengan perbuatan maupun benda yang dibangun berdasarkan pandangan hidup tertentu.

Dengan ini, dapat kita pahami begitu pentingnya akal, sebagai salah satu potensi manusia untuk mengontrol dan mengatur pemenuhan potensi kehidupan (kebutuhan jasmani dan naluri) manusia, agar berjlan dengan baik, sehingga manusia tidak sama dengan binatang. Dengan catatannya selalu dikaitkan dengan kaidah berfikir Islam. 48

47 Taqiyuddin An Nabhani, Pilar-pilar Pengokoh Nafsiyah Islamiyah, (Jakarta: HTI Press, 2016), 9

${ }^{48}$ M. Zain Sharifuddin, Studi Islam Paradigma Komprehensif, (Bogor: Al Azhar Press, 2014), 33. 


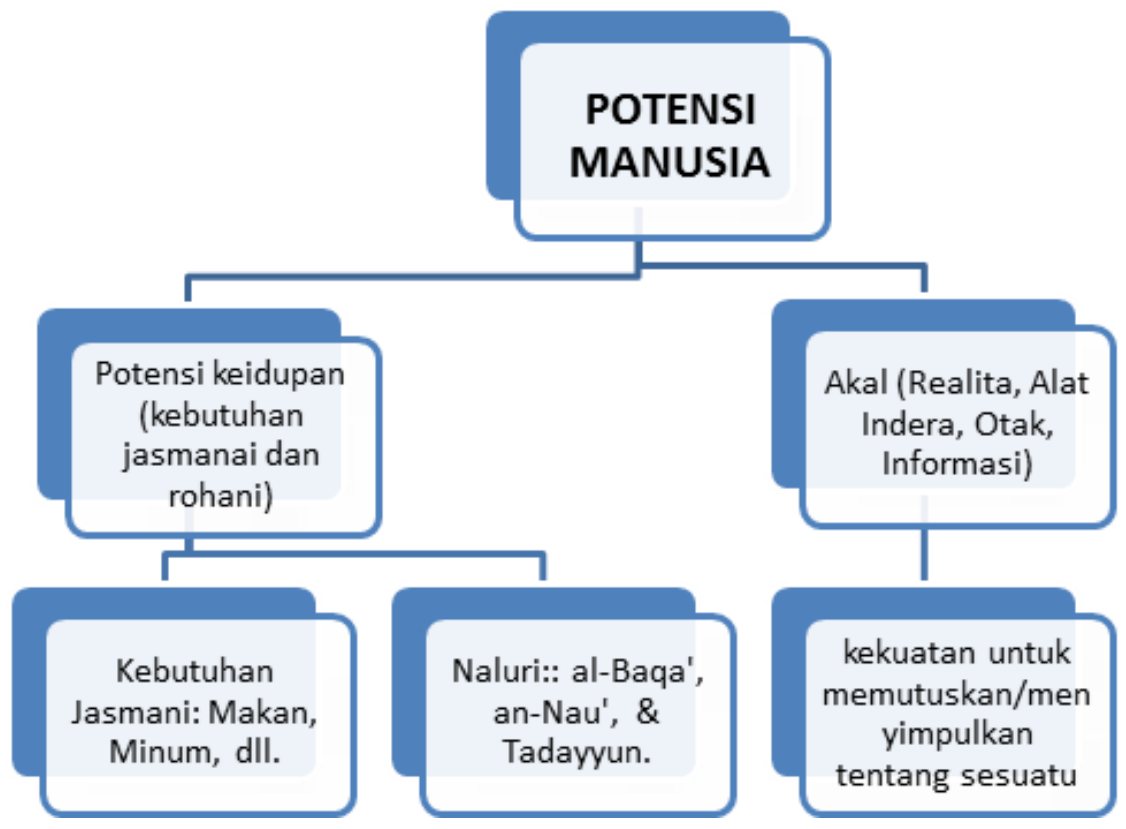

Aqliyah adalah metode yang digunakan oleh seseorang untuk mengasosiasikan antara realitas yang dihadapi dengan informasi awal yang dimilikinya dengan cara mengembalikannya kepada suatu kaidah atau beberapa kaidah tertentu. Karena aqliyah ini bisa manusia menghukumi atau menyimpulkan, dan mengasosiasikan antara realitas dan informasi yang bisa dijadikan standar perbuatan atau kaidah syara'. ${ }^{49}$

Meskipun hal ini benar, tetapi yang perlu dipertimbangkan adalah bahwaakal dideskripsi mengenai suatu fakta, dan yang dikehendaki dari definisi akal harus dibangun atas dasar realitas yang ada dan dapat di indera, karena yang dikehendaki adalah agar seluruh manusia terikat dengan definisi tersebut. 50

${ }^{49}$ M. Zain Sharifuddin, Studi Islam Paradigma Komprehensif, (Bogor: Al Azhar Press, 2014), 68.

${ }^{50}$ M. Zain Sharifuddin, Studi Islam Paradigma Komprehensif, (Bogor: Al Azhar Press, 2014), 9. 


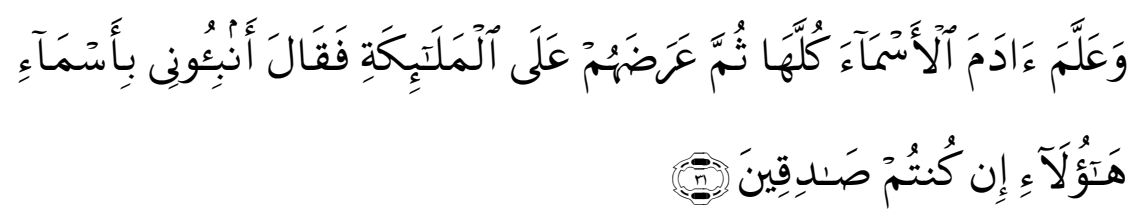

Artinya: Dan Dia mengajarkan kepada Adam nama-nama (bendabenda) seluruhnya, kemudian mengemukakannya kepada para Malaikat lalu berfirman: "Sebutkanlah kepada-Ku nama benda-benda itu jika kamu mamang benar orang-orang yang benar!"(QS. Al Baqarah: 31)

Ayat ini menunjukkan bahwa informasi terdahulu mesti ada untuk sampai pada pengetahuan apapun. Manusia pertama, yaitu Nabi Adam, sesungguhnya teah diberi sejumah informasi oleh Allah hingga ia bisa mengetahui nama-nama benda. Oleh karena itu, ketika benda-benda tersebut diperlihatkan ke hadapan Adam, dia langsung mengetahuinya. Seandainya saja berbagai informasi tersebut tdak ada, adam tentu tidak akan mengetahuinya.

Potensi akal tidak termasuk dalam potensi kehidupan, karena manusia masih bisa hidup meskipun potensi akalnya hilang (tidur, pingsan dan mabuk) atau belum sempurna (masih kecil). Meskipun begitu, akal memiliki peranan penting dalam kehidupan manusia, karena dengan potensi akalnya mampu menciptakan peradaban tinggi untuk meningkatkan kualitas hidupnya. Potensi akal berfungsi menstransfer fakta melalui alat indera kedalam otak, kemudian informasi-informasi terdahulu digunakan untuk: menilai, memberi nama, memahami, menghukumi, manfsirkan, atau menginterpretasi fakta tersebut. Potensi kehidupan dan potensi akal tidak datang dengan sendirinya dari materi, karena yang menetapkan potensi-potensi tersebut adalah Allah.

Unsur rohani manusia dikaitkan dengan kehidupan duniawi adalah akal dan nafsu. Nafsu mendorong akal manusia untuk mencari cara hidup, nafsu yang mendorong manusia untuk hidup berkeluarga dan melanjutkan keturunan, serta nafsu juga yang membuat manusia hidup dinamis di dunia ini. ${ }^{51}$

${ }^{51}$ Haris Fadillah dan Mufida Istati, "Kesiapan Kerja Dalam Kepribadian Islami Mahasiswa", Jurnal Koseling Gusjigang, Vol. 3, No. 2, Juli-Desember 2017, h. 214 
Karena cara berfikir masing orang berbeda, tetu cara berffikir orang Islam yang menggunakan kaidah berbeda dengan orang non-muslim dalam melihat benda. Jika kaidah yang dijadikan standar orang muslim adalah halal dan haram atau: "hukum asal benda adalah mubah, selama tidak ada dalil yang mengharamkannya." Maka kaidah yang menjadi standar orang kapitalis dan sosialis adalah: "hukum asal benda dikembalikan kepada nilai kegunannya".

Jadi aqliyah Islamiyah (pola pikir Islam), adalah berpikir berdasarkan Islam, yang menjadikan Islam sebagai satu-satunya tolak ukur umum terhadap seluruh pemikiran terhadap kehidupan. Jadi, bukan hanya sekedar pola pikir intelektual atau cendikiawan. Selama seseorang menjadikan Islam sebagai tolak ukur atas seluruh pemikirannya secara pragtis dan riil, berarti ia telah memiliki aqliyah Islami.

\section{Nafsiyah Islamiyah (Pola Sikap Islam)}

Sedangkan yang dimaksud dengan nafsiyah (pola sikap) Islam adalah menjadikan seluruh kecenderungan (muyul)nya bertumpu pada asas Islam, yaitu menjadikan Islam sebagai satusatunya tolak ukur umum terhadap seluruh pemenuhan (kebutuhan jasmani maupun naluri). Jadi bukan hanya bersikap keras atau menjauhkan diri dari dunia.Selama seseorang menjadikan hanya Islam saja sebagai tolak ukur atas seluruh pemenuhan(kebutuhan jasmani maupun naluri)nya secara praktis dan secara riil, berarti dia telah memiliki nafsiyah (pola sikap) Islam. ${ }^{2}$ Namun, ketika pemenuhan tersebut tidak dilakukan dengan cara seperti itu, berarti nafsiyah (pola sikap)nya merupakan nafsiyah(pola sikap) yang lain. ${ }^{53}$

Islam telah menawarkan solusi untuk pemenuhan seluruh kebutuhannya secara teratur, yang membawa pada ketentraman dan ketenangan. Oleh karena itu menurut Taqiyuddin An Nabhani apabila seorang Muslim yang memeluk Islam melalui proses berpikir dan bukti, menerapkan Islam pada dirinya secara total, memahami hukum-hukum Allah dengan pemahaman yang

52 Taqiyuddin An Nabhani, Syakhshiyah Islam kepribadian Islam, jilid 1, terjemah zakia Ahmad, (Bogor:Pustaka Thariqul Izzah, 2003), h. 7

53 Taqiyuddin An Nabhani, Pilar-pilar Pengokoh Nafsiyah Islamiyah, (Jakarta: HTI Press, 2016), h. 10 
benar, maka si Muslim tadi memiliki kepribadian Islam yang berbeda dengan (kepribadian) lainnya. ${ }^{54}$

Seseorang yang berkepribadian Islam memilki'aqliyah (pola pikir) Islam dengan menjadikan akidah Islam sebagai dasar dalam pemikirannya. Ia memiliki nafsiyah (pola sikap) Islam dengan menjadikan akidah Islam sebagai dasar dalam kecenderungannya. Berdasarkkan hal ini maka syakhshiyah (kepribadian) Islam itu memiliki sifat khusus yang pasti melekat pada diri orang tersebut.

Selanjutnya menurut Taqiyuddin An Nabhani bahwa seseorang yang berkepribadian Islam sifatnya yang paling tinggi adalah sebagai hamba Allah, Sang Pencipta. Ia adalah yang khusyu' dalam shalatnya, berpaling dari perkataan yang sia-sia, membayar zakat dan menundukkan pandangannya, menjaga amanat-amanatnya, memenuhi kesepakatannya, menunaikan janji-janjinya dan berjihad di jalan Allah. Itulah seorang muslim, dan ituah pula seorang mukmin. Dan inilah kepribadian (syakhshiyah) Islam yang dibentuk oleh Islam, dan menjadikannya manusia sebaik-baik ciptaan.Allah telah menyebutkan ciri-ciri kepribadian tersebut di dalam Al-Quran yang mulia pada banyak ayat. Disebutkannya sebagai sifat-sifat para sahabat Rasulullah saw, sifat-sifat orang mukmin, sifat-sifat hamba Allah ('ibadurrahman), dan sifat-sifat mujahid." ${ }^{55}$ seperti yang Allah SWT firmankan di Surat Al-Mu'minun:

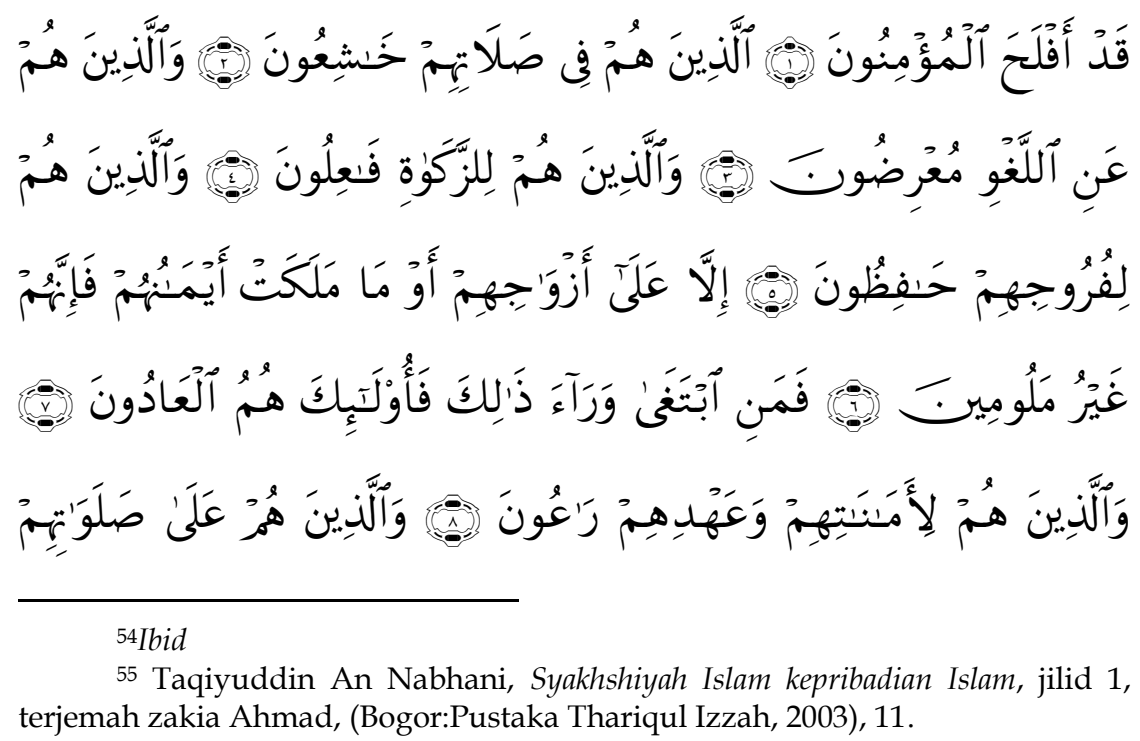




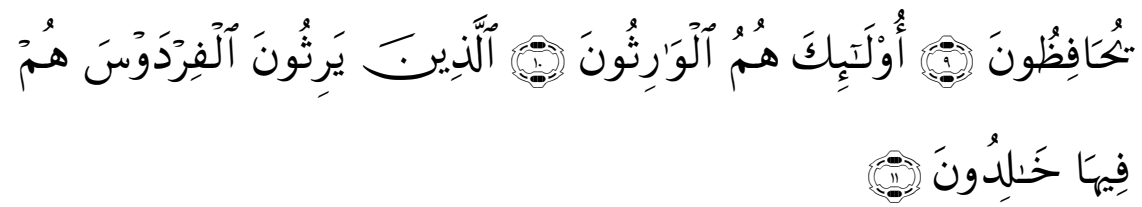

"(1)Sesungguhnya beruntunglah orang-orang yang beriman, (2)(yaitu) orang-orang yang khusyu' dalam sembahyangnya, (3)dan orang-orang yang menjauhkan diri dari (perbuatan dan perkataan) yang tiada berguna, (4)dan orang-orang yang menunaikan zakat, (5)dan orangorang yang menjaga kemaluannya, (6)kecuali terhadap isteri-isteri mereka atau budak yang mereka miliki; maka sesungguhnya mereka dalam hal ini tiada tercela, (7)Barangsiapa mencari yang di balik itu maka mereka itulah orang-orang yang melampaui batas, (8)Dan orangorang yang memelihara amanat-amanat (yang dipikulnya) dan janjinya, (9)dan orang-orang yang memelihara sembahyangnya, (10)Mereka itulah orang-orang yang akan mewarisi, (11)(yakni) yang akan mewarisi surga Firdaus. Mereka kekal di dalamnya." (QS. AlMu'minun, 23:1-11) 56

\section{Konsep kepribadian Islam Menurut Taqiyuddin An Nabhani}

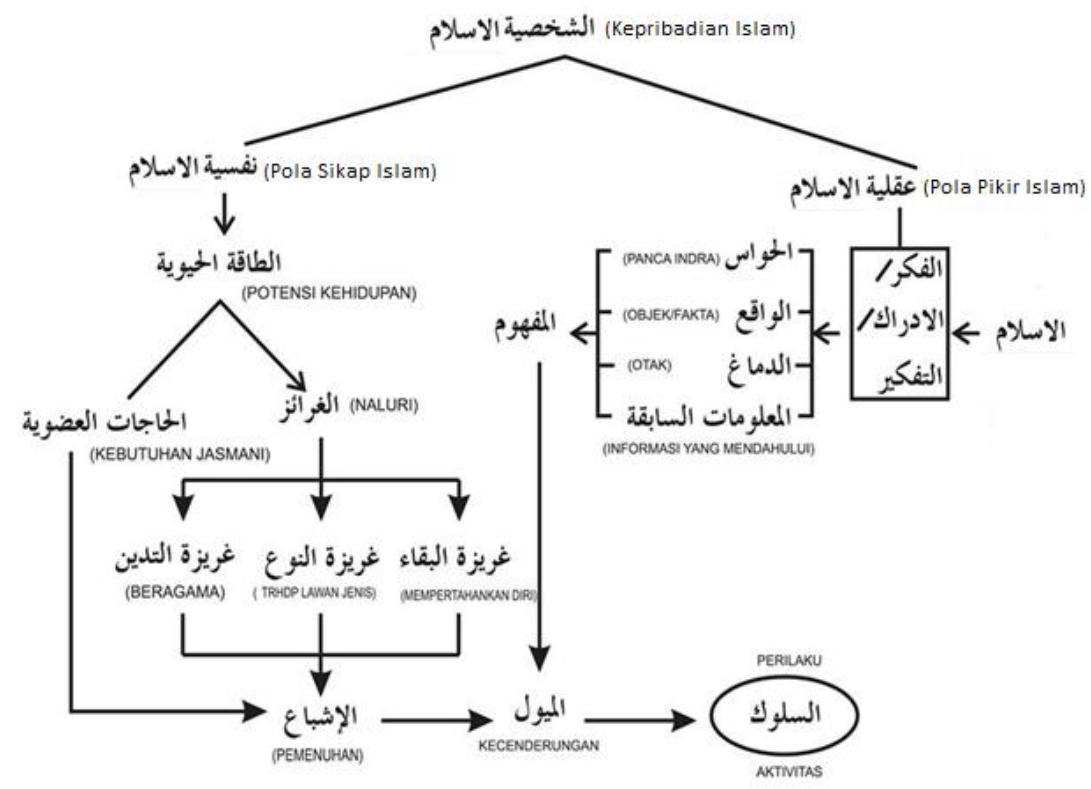

56 Via Al-Qur'an Indonesia http:/ / quran-id.com 
Berdasarkan paparan pendapat Taqiyuddin An Nabhani diatas bahwa selama manusia memiliki sirrul hayat (nyawa) dalam dirinya, maka potensi dalam dirinya akan selalu menuntut untuk dipenuhi baik hajatul 'udhawiyah (kebutuhan jasmani) maupun ghara'iz (naluri-naluri). Ghara'iz (naluri-naluri)menuntut pemenuhan namun apabila tidak dipenuhi, akibatnya tidak akan sampai pada menyebabkan kematian, hanya saja bisa menimbulkan kegelisahan. Adapun rangsangan pada naluri ini bersifat eksternal.

\section{Kesimpulan}

Manusia dalam pandangan Taqiyuddin An Nabhani adalah materi yang apabila terdapat ruh dalam artian sirrul hayat (nyawa) maka potensi yang berupa hajatul 'udhawiyah (kebutuhan jasmani) dan Gharaiz (naluri-naluri)nya akan selalu menuntut untuk dipenuhi dan cara pemenuhannya tergantung pada 'aqliyah (pola pikir) dan nafsiyah (pola sikap)nya.

Apabila ia memiliki aqliyah Islam, yakni ketika seseorang memikirkan sesuatu untuk mengeluarkan keputusan hukum terhadapnya dengan menyandar kepada akidah Islam dan nafsiyah Islam, yakni ketika pemenuhan naluri dan kebutuhan jasmani tersebut dilaksanakan dengan sempurna berdasarkan akidah Islam sekaligus, baru ia bisa dikatakan sebagai orang yang memiliki syakhshiyah Islam (kepribadian Islam).

Jika sifat Islami hanya ada pada salah satunya maka tidak bisa dikatakan ia memiliki syakhshiyah Islam (kepribadian Islam). Aqliyah (pola pikir) dan nafsiyah (pola sikap) pada seseorang adalah hasil bentukan manusia itu yaitu dari apa yang ia pikirkan dan dari apa yang ia pelajari.

Tetapi bukan berarti dalam diri pelakunya tidak akan pernah ada kecacatan. Tetapi (kalaulah ada), kecacatan tersebut tidak akan mempengaruhi syakhshiyah (kepribadian)nya selama kecacatannya bukan perkara pangkal (dalam kepribadiannya), melainkan pengecualian (kadang terjadi, kadang tidak). karena manusia bukanlah malaikat. Dia bisa saja melakukan kesalahan, lalu memohon ampunan dan bertaubat.Bisa juga dia melakukan kebenaran, lalu memuji Allah atas kebaikan, karunia, dan hidayah-Nya. 


\section{Daftar Pustaka}

2015, Sistem Pergaulan dalam Islam, Jakarta Selatan: HTI Press.

2016, Peraturan Hidup dalam Islam, Penj. Abu Amin, Jakarta Selatan: HTI Press.

2016, Pilar-pilar Pengokoh Nafsiyah Islamiyah, Jakarta: HTI Press.

Abdullah, Muhammad Husain, 2002, Mafahim Islamiyah, Bangil: al Izzah.

An Nabhani, Taqiyuddin,2003, Hakekat Berpikir, penj. Taqiyuddin As Siba'i, Bogor: Pustaka Thariqul Izzah.

Anton Widodo, Fathur Rohman, Konsep Jiwa Yang Tenang Menurut Surta Al Fajr Ayat 27-30 (Perspektif Bimbingan Penyuluhan Islam), Al-Irsyad: Jurnal Bimbingan Penyuluhan Islam,Vol.1. No.2 Juli-Desember

Asy Syafi'i dalam Arief B. Iskandar, 2015, Materi Dasar Islam Islam Mulai Akar Hingga Daunnya, Bogor: Al Azhar Press.

El-Haq Iwandi, Gus Din, "Metode Pembentukan Kepribadian Islami Menurut Syaikh Taqiyuddin An-Nabhani" Al-Fikra: Jurnal Ilmiah Keislaman, Vol 17, No 2, Juli-Desember 2018.

Fadillah, Haris, dan Istati, Mufida, "Kesiapan Kerja Dalam Kepribadian Islami Mahasiswa", Jurnal Koseling Gusjigang, Vol. 3, No. 2, Juli-Desember 2017.

Hafizh Abdurrahman, 2010, Diskursus Islam Politik dan Spiritual, Bogor: Al Azhar Press.

Hidayat, Dede Rahmat, 2015, Teori dan Aplikasi Psikologi Kepribadian Dalam Konseling, Bogor: Ghalia Indonesia.

Ismail, Muhammad, 2004, Refreshing Pemikiran Islam, Bangil: al Izzah.

Jamilah, Siti, "Gerakan Hizbut Tahrir di Kota Pare-Pare (Membaca Pengaruh Pemikiran Taqiyuddin al-Nabhani)", Jurnal Diskursus Islam, Vol. 3, No. 1, Tahun 2015. 
Rodhi, Muhammad Muhsin, 2012, Tsaqofah Dan Metode Hizbut Tahrir Dalam Mendirikan Negara Khilafah, penj. Muhammad Bajuri \& Romli Abu Wafa, Bogor: Al Azhar Press.

Saktiyono, Purwoko, 2012, Psikologi Islami, Bandung: Saktitoyono Wordpress.

Silahudin, Agus, "Perbandingan Konsep Kepribadian Menurut Barat dan Islam" Al-Fikra: Jurnal Ilmiah Keislaman, Vol. 17, No 2, Juli-Desember 2018.

Sukmadinata, Nana Syaodih, 2007, Metode Penelitian Pendidikan,Bandung: PT Remaja Rosdakarya.

Sulistiawati dan Fuad, Ahmad, "Konsep Kepemilikan dalam Islam Studi Atas Pemikiran Syaikh Taqiyuddin anNabhani", Jurnal Syariah, Vol. V, No. 2, Oktober 2017 